\title{
QUANTIFYING WILDLIFE USE OF CAVE ENTRANCES USING REMOTE CAMERA TRAPS
}

\author{
GRETCHEN M. BAKER \\ Great Basin National Park, 100 Great Basin National Park, Baker, NV89311,gretchen_baker@nps.gov
}

\begin{abstract}
Digital infrared remote camera traps were placed at the entrance of twelve caves in Great Basin National Park, Nevada during the summer of 2013 to assess the wildlife use of cave entrances. The use of caves by surface wildlife is a major nutrient source for cave organisms that spend their entire lives underground. Cave entrances varied in size ( 0.9 to $50 \mathrm{~m}^{2}$ ), cave length (10 to $1000 \mathrm{~m}$ ), surface habitat (riparian versus pinyon/juniper), and management approach (gated versus no gate). Data from eight cave entrances are presented, with four other entrances removed from the analysis due to equipment failure. The cameras were deployed for a total of 372 trap days, with an average of 46.5 days per cave (range 28 to 62 ). The cameras captured 632 trap events, with separate events defined as more than an hour apart for the same species. Of the seventeen taxa documented, the most abundant species photographed were mice, chipmunks, humans, woodrats, and squirrels. Other species observed in cave entrances were cottontail rabbits, bats, skunks, foxes, insects, birds, and domestic dogs. Wildlife entered and exited caves most frequently between 1800 and 0600 . Very little information has been previously documented about fauna using cave entrances, and this non-invasive, repeatable technique can help managers learn more about the dominant species using the entrance and twilight areas of the caves they manage, as well as peak use times.
\end{abstract}

\section{INTRODUCTION}

Cave entrances provide important habitat to wildlife. Cave entrances can offer a thermal and moisture refuge from above-ground conditions, particularly in desert areas where summer daytime and winter nighttime temperatures can vary more than $30{ }^{\circ} \mathrm{C}$ from the relatively steady temperature found underground (Cigna, 2004). Cave entrances provide shelter for a wide variety of vertebrate and invertebrate species that may not use deeper cave environments. They serve as food caching locations for many animals, including mice. In the American West, they frequently provide suitable habitat for nesting cave swallows (Petrochelidon fulva) as well as woodrats (Neotoma spp.). Over 44,000 caves are known within the United States (Culver et al., 1999). Many caves have an interesting and varied fauna, including many species that are cave obligates. Despite knowledge of what lives in caves, few studies have focused on wildlife use of the transition zone between above and below ground, especially in desert environments (Winkler and Adams, 1972; Strong, 2006; Strong, 2010).

Two main types of wildlife, cave accidentals and trogloxenes, use cave entrances. The facultative use of cave entrances by cave accidentals like beetles and lizards, and the regular use by trogloxenes, such as bats and cave crickets, are critical to cave ecosystems. These wildlife species introduce energy into the nutrient-poor environments in the form of scat, nesting materials, and occasionally carcasses. These deposits provide a nutrient source for troglophiles, species that can complete their entire life cycle in the cave or in a similar habitat aboveground, and troglobites, cave-adapted organisms that never leave caves (Barr and Holsinger, 1985). Therefore, to better understand the nutrient flow into the cave, it is logical to study the use of the cave by cave accidentals and trogloxenes at their point of entrance.

Remote camera trapping, or using remote cameras to take photographs of animals, is a non-invasive technique to study wildlife use. This technique can capture rare and elusive species, monitor animal behavior, and document predation (Kucera and Barrett, 2011). Camera traps can also sample locations where it would be uncomfortable for a person to stay for long. Cameras work both day and night, so diurnal, nocturnal, and crepuscular animals are sampled. In addition, multiple species can be studied at the same time. Studies using remote cameras in various habitats such as forests, shrublands, and riparian areas have been conducted for decades (Kucera and Barrett, 2011), but they have not been reported for cave entrances.

The primary objective of this study is to fill an information gap about which wildlife species use cave entrances, when they use them, and to what extent other variables may influence usage. In particular, I focused on entrance usage by time of day, vegetative habitat above ground, entrance size, and cave gate presence or absence. This information can help managers better understand the role cave entrances play for surface wildlife, as well as better comprehend the role surface wildlife has on nutrient input into caves.

\section{Methods}

The study area is located in Great Basin National Park in east-central Nevada (Fig. 1), part of the Basin and Range 

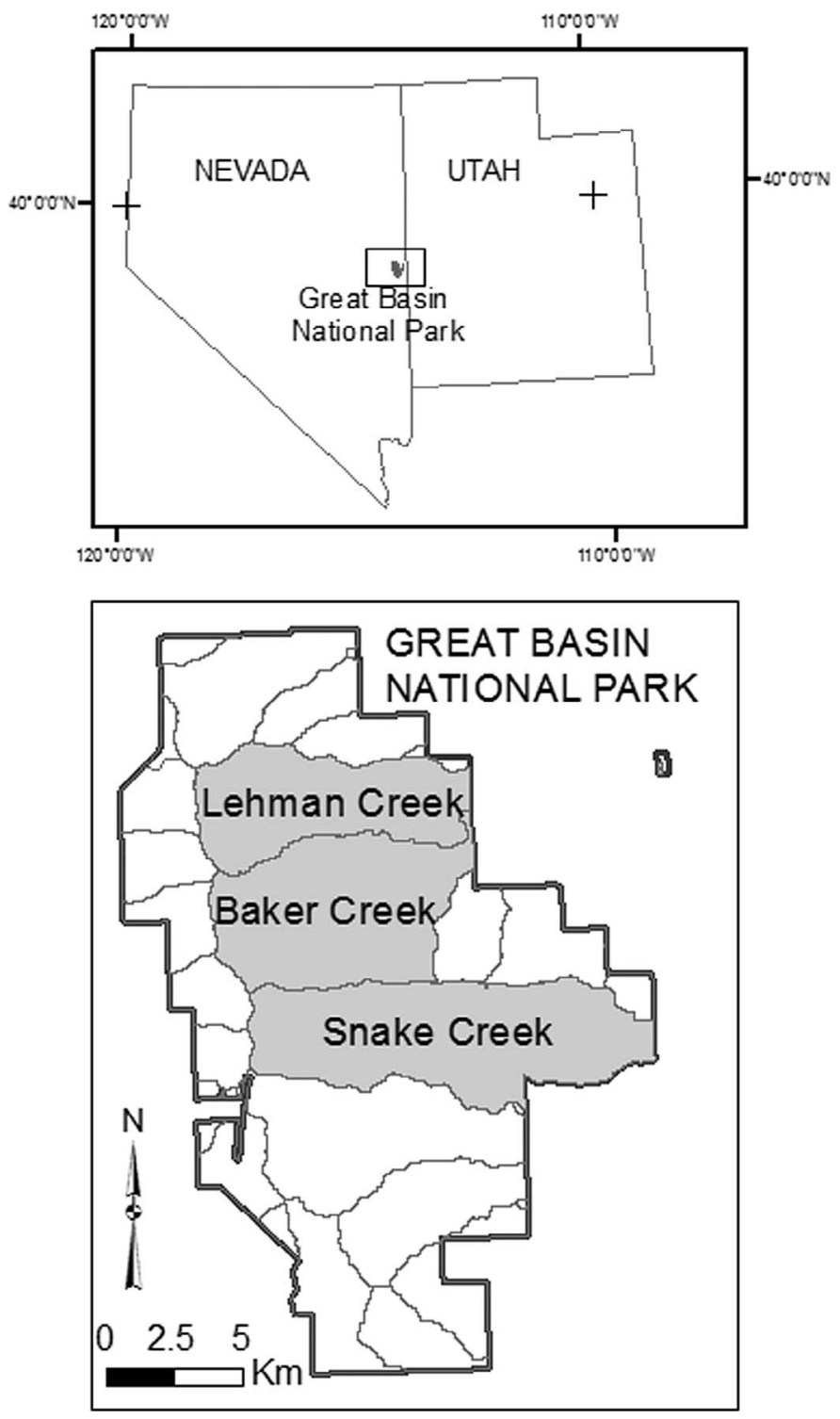

Figure 1. General location of Great Basin National Park, White Pine County, Nevada, and location of study watersheds (Lehman, Baker, and Snake) within the park.
Province. The park encompasses much of the southern Snake Range, which is considered a metamorphic core complex of Proterozoic to Middle Cambrian age. About $40 \%$ of the surface rock at the park consists of karst, primarily Middle Cambrian to Ordovician limestones (Hose and Blake, 1976; Miller et al., 1987; Graham, 2014). Elevations in the park range from 1,600 to over $3,900 \mathrm{~m}$. The climate is typical of the high desert, with summer highs exceeding $30{ }^{\circ} \mathrm{C}$ and winter lows below $-20{ }^{\circ} \mathrm{C}$ at the park headquarters, located at 2,070 m. Annual precipitation at this elevation averages $33 \mathrm{~cm}$, with precipitation increasing and temperatures decreasing as one rises in elevation (Elliott et al., 2006; Reinemann et al., 2011).

Twelve caves were selected in the Lehman, Baker, and Snake Creek watersheds based on their accessibility, within a ten-minute walk, and size, at least $12 \mathrm{~m}$ in length. The caves were located at elevations from 2,020 to $2,235 \mathrm{~m}$ in Middle Cambrian Pole Canyon limestone in the Baker and Lehman watersheds and in the Notch Peak limestone in the Snake watershed. Nearby habitat consisted of pinyon pine (Pinus monophylla) and Utah juniper (Juniperus osteosperma) woodlands or riparian habitat dominated by water birch (Betula occidentalis). Half the caves were gated, and half were not gated. Entrance areas ranged from $0.9 \mathrm{~m}^{2}$ to $50 \mathrm{~m}^{2}$. Lengths of the caves ranged from $10 \mathrm{~m}$ to $1000 \mathrm{~m}$, with a mean length of $250 \mathrm{~m}$. Data were successfully obtained from eight of the caves (Table 1).

Four models of infrared-triggered wildlife cameras were installed at the caves: Cuddeback Expert $(n=1)$, Cuddeback NoFlash $(n=2)$, Reconyx PC $90 \mathrm{HO}(n=2)$, and Reconyx PC $85(n=2)$. The Cuddeback cameras took one photo per trigger, whereas the Reconyx cameras took one to three photos per trigger. Cameras were mounted with bungee cords or bailing wire to rocks and signs or were propped up with rocks where appropriate flat surfaces were present. Cameras were aimed at or across the cave entrance, but not pointed directly into the rising or setting sun. No lures or bait were used for this study.

The total number of photographs taken, events, and trap days of effort were summarized after subtracting the days

Table 1. Caves selected for remote camera study in Great Basin National Park, White Pine County, Nevada.

\begin{tabular}{lclcccc}
\hline Cave Name & $\begin{array}{c}\text { Entrance size } \\
\text { (in m; width } \times \text { height) }\end{array}$ & Gated? & Length, $\mathrm{m}$ & Elevation, $\mathrm{m}$ & Habitat type & Watershed \\
\hline Fox Skull Cave & $3 \times 2$ & $\mathrm{No}$ & 60 & 2020 & Pinyon/Juniper & Snake \\
Ice Cave & $2 \times 3 ; 2 \times 4^{\mathrm{a}}$ & $\mathrm{No}^{\mathrm{b}}$ & 900 & 2150 & Riparian & Baker \\
Lower Pictograph Cave & $10 \times 5$ & $\mathrm{No}$ & 12 & 2140 & Riparian & Baker \\
Model Cave & $2 \times 1$ & Yes & 590 & 2080 & Riparian & Baker \\
Root Cave & $1 \times 1.5$ & Yes & 120 & 2090 & Pinyon/Juniper & Lehman \\
System's Key Cave & $0.5 \times 0.5$ & Yes & 300 & 2120 & Riparian & Baker \\
Three Hole Cave & $1 \times 1,1 \times 1.2^{\mathrm{a}}$ & $\mathrm{No}$ & 10 & 2120 & Pinyon/Juniper & Baker \\
Wheeler's Deep & $2 \times 3$ & Yes & 1000 & 2150 & Pinyon/Juniper & Baker \\
\hline
\end{tabular}

${ }^{a}$ Ice Cave and Three Hole Cave both have two entrances, and cameras were alternated between the entrances.

${ }^{b}$ Ice Cave is gated, but the cameras were placed at the ungated section of the cave.

'System's Key is gated, and the camera was placed at the gate and later above the gate, which showed a wider variety of animal life. 


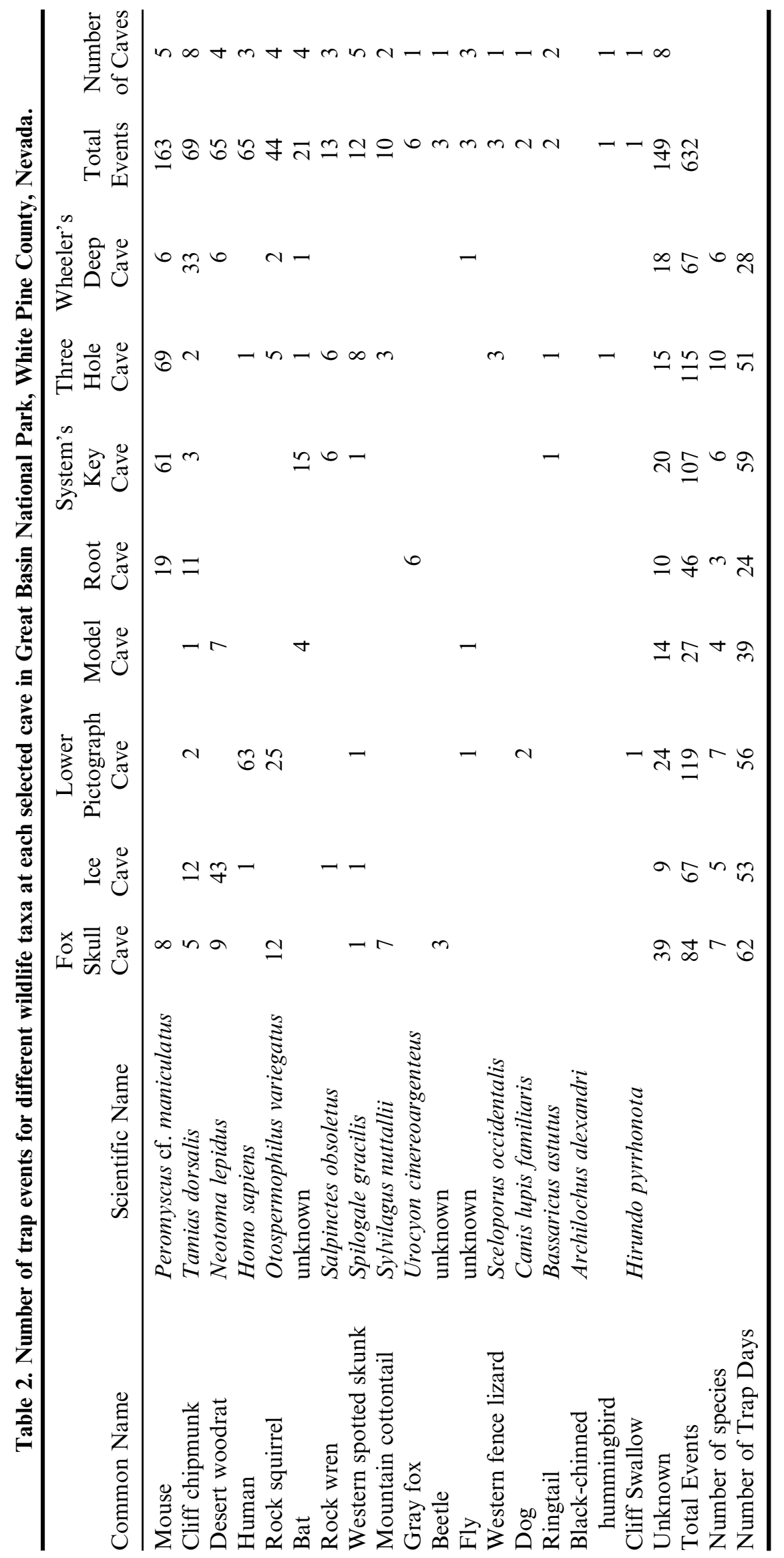




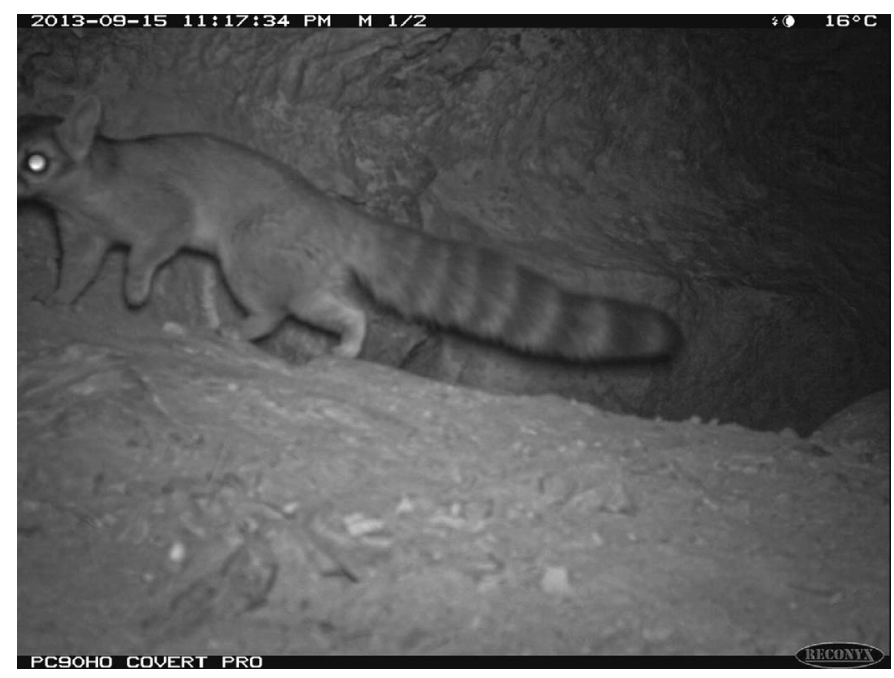

Figure 2. A ringtail (Bassaricus astutus) outside of System's Key Cave at Great Basin National Park, White Pine County, Nevada.

that the camera malfunctioned, most commonly due to battery failure. Animals that could not be distinguished as individuals and that were captured within one hour of each other were considered to be the same event. After one hour, they were arbitrarily considered to be a new photographic event. All photos were examined at least two times, with wildlife-biologist consultation as needed to reach the lowest taxonomic level feasible, usually species. Microsoft Excel (v. 2007) and Minitab Statistical Software version 14 (www.minitab.com) were used to perform data analyses. Values are presented as means \pm standard deviation.

\section{RESUlts}

Cameras were deployed at various caves from May 30 to September 20, 2013 (Table 2). During the 113-day study period, the cameras recorded 372 trap days, with $46.5 \pm$ 14.4 days of effort per cave (range of 28 to 62) for eight caves. Cameras at four caves (Lehman Annex, Upper Pictograph, Snake, and Squirrel Springs) malfunctioned, and their data were not included in the analysis. Seventy-six percent of the trap events had identifiable taxa, to species level except for some mice, bats, and invertebrates.

Camera traps documented a minimum of seventeen taxa at the cave entrances. The most common animals captured by the cameras were mice, with 163 trap events (Table 2; includes scientific names). These were followed by cliff chipmunks, humans, desert woodrats, rock squirrels, and bats. Several species were only captured ten to fifteen times, including western spotted skunks, mountain cottontails, and rock wrens. Gray foxes were only captured six times, all at one cave. Ringtails (Fig. 2) were even more elusive, being recorded only twice.
Some taxa were more widespread across cave entrances than others. Chipmunks were found at all eight cave entrances, and mice were found at five of the eight cave entrances. Squirrels, desert woodrats, birds, and bats were recorded at four cave entrances. However, four taxa were found at only one or two cave entrances. The number of taxa per cave entrance varied from three at Root Cave to ten at Three Hole Cave, with a mean of $6.0 \pm 2.1$ per cave. Species accumulation curves are shown in Figure 3.

The number of trap events per cave ranged from 27 at Model Cave to 119 at Lower Pictograph Cave, an average of $79 \pm 33$ trap events per cave. To compensate for the varying efforts at the caves, the trap events per camera day were calculated, with a resulting catch of $1.7 \pm 0.6$ trap events per camera day, with a range of 0.7 trap events per camera day at Model Cave to 2.4 trap events per camera day at Wheeler's Deep Cave.

At the three caves equipped with Reconxy 85 cameras that took three photos for each trigger, the first photo identified the species $73 \%$ of the time, while the second photo accounted for $5 \%$ and the third photo for $2 \%$ of the identifications. The second and third photos did not add to species richness. In $20 \%$ of the trap events, the species was not identifiable or was absent from the photos.

Sixty-four percent of trap events occurred during the twelve-hour period between 1800 and 0600 (Fig. 4). Some wildlife species showed distinct preference for particular time periods (Fig. 5). Animals most active at night were bats, mice, skunks, and ringtails. Animals most active during the day were chipmunks, humans, birds, and squirrels. Although woodrats were primarily nocturnal, at Three Hole Cave they showed a surprising tendency to be active during daylight hours as well. Cottontails (Fig. 6) were captured at all hours of the day and night except from 0900 to 1300 .

Although ungated caves had a higher number of trap events $(n=413)$ than gated caves $(n=248)$, the difference between the medians was not significant $(p=0.113)$, using a Mann-Whitney $U$ test. Likewise, the difference between pinyon/juniper and riparian habitats was not significant using a Mann-Whitney $\mathrm{U}$ test. A regression did not show the length of cave $(p=0.197)$ or cave entrance size $p=$ 0.260 ) to significantly predict different numbers of wildlife. However, some taxa were more common with certain conditions (Fig. 7). Ungated caves accounted for all human visits, as well as $95 \%$ of squirrel and $80 \%$ of woodrat trap events. Ninety-five percent of bats and $70 \%$ of chipmunks were seen at gated caves. No taxa showed a preference for cave entrances in pinyon/juniper areas, but $99 \%$ of human, $95 \%$ of bat, $86 \%$ of woodrat, and $74 \%$ of chipmunk trap events were found at caves with entrances in riparian areas. The four longer caves $(>250 \mathrm{~m})$ accounted for $95 \%$ of bat and $70 \%$ of chipmunk trap events, while $100 \%$ of human, $91 \%$ of squirrel, and $80 \%$ of woodrat trap events were at shorter caves.

Journal of Cave and Karst Studies, December 2015 • 203 


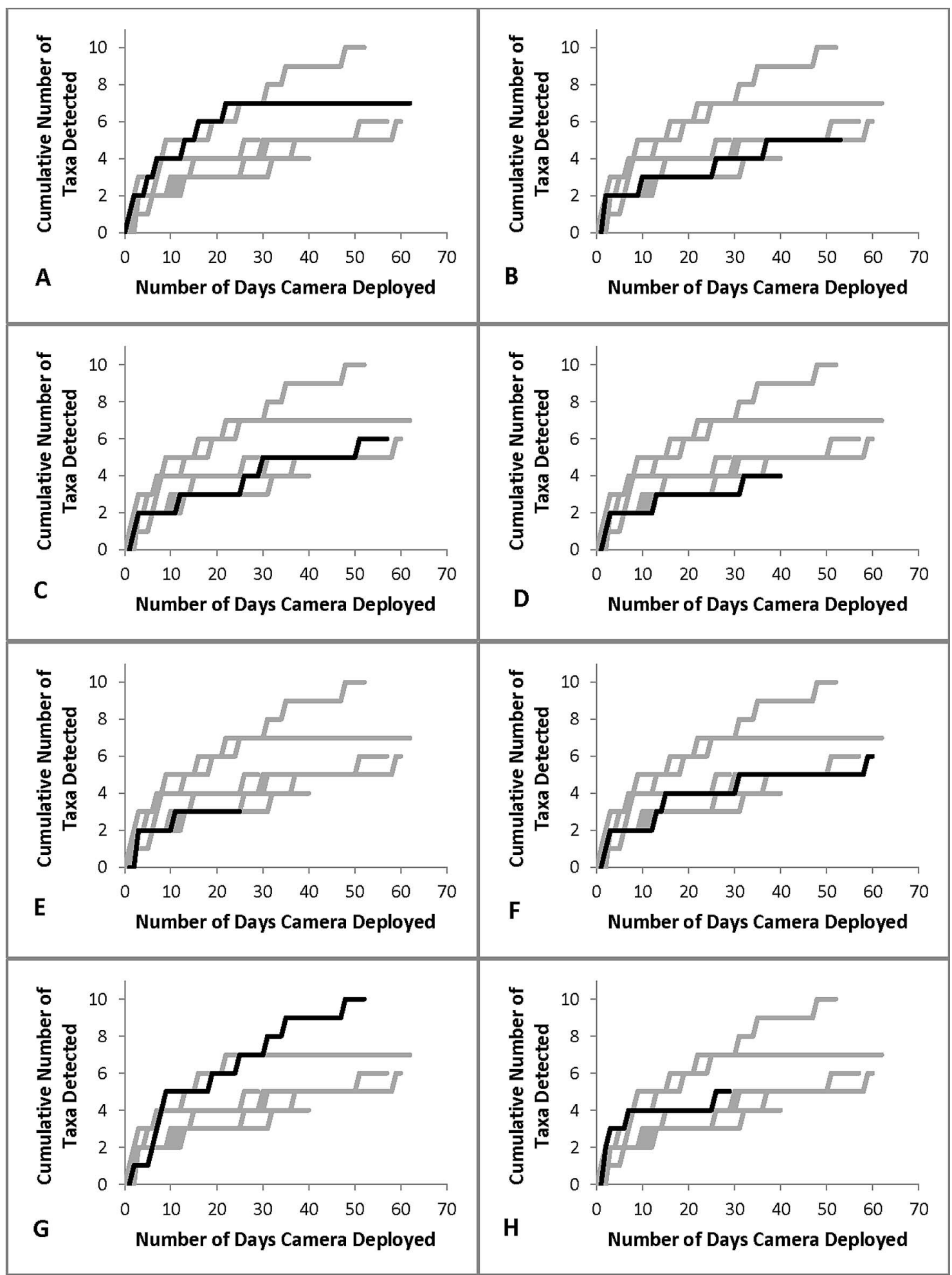

Figure 3. Species accumulation curves from wildlife camera events for each of the eight caves studied at Great Basin National Park, White Pine County, Nevada. A-Fox Skull Cave, B-Ice Cave, C-Lower Pictograph Cave, D-Model Cave, E-Root Cave, F-System's Key Cave, G-Three Hole Cave, H-Wheeler's Deep Cave. Each cave is shown in black, with the other seven caves in gray for context. 


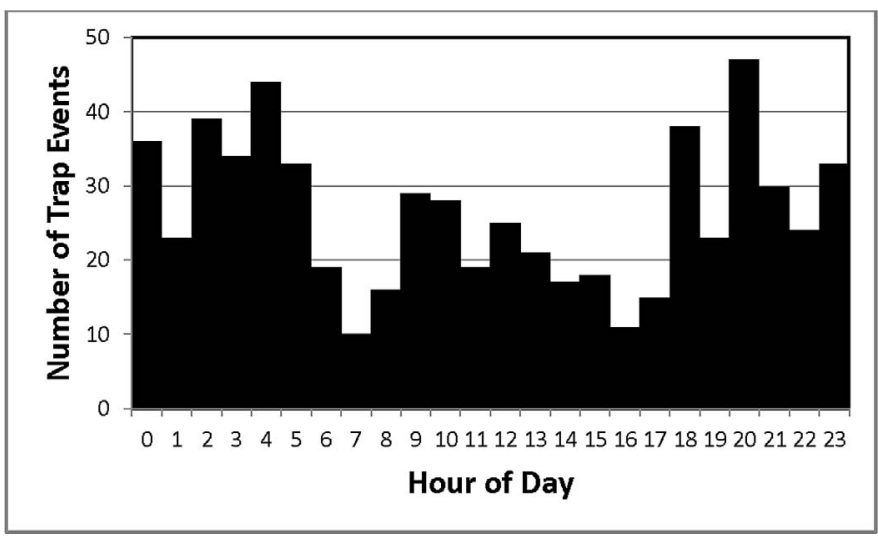

Figure 4. Total number of wildlife camera trap events pooled by hour of day for all eight caves sampled in Great Basin National Park, White Pine County, Nevada.

\section{Discussion}

Previous information about overall wildlife use of cave entrances is extremely limited (Winkler and Adams, 1972; Strong, 2006; Strong, 2010), but this low-cost, low-personneleffort provided a baseline of summer use for multiple cave entrances. In addition to informing managers as to what animals use the cave entrances, the camera traps also allowed a glimpse into the peak times of use and showed habitat preferences for some taxa.

No species were captured that had not been previously documented in the park in other habitats. However, this study was the first to document the use of park cave entrances by several species, including western fence lizard, gray fox, domesticated dog, ringtail, western spotted skunk, rock squirrel, rock wren, black-chinned hummingbird, and cliff swallow. Previous studies (Desert Research Institute, 1968; Stark, 1969; Krejca and Taylor, 2003; Taylor et al., 2008) noted use of park caves by taxa also found in this study: bats, humans, cliff chipmunks, mountain cottontails, woodrats, mice, beetles, and flies. This study expanded the number of caves and the seasons of use by these taxa. The previous studies also found kit fox, black-tailed jackrabbit, broad-tailed hummingbird, and canyon wren use of caves. Taylor et al. (2008) noted that in their biological inventories of 15 caves in Great Basin National Park, evidence of woodrats was found in nearly every cave, but no live specimens were ever seen. This study photographed desert woodrats at half of the caves studied. With regards to small mice, previous studies (Desert Research Institute, 1968; Stark, 1969; Krejca and Taylor, 2003; Taylor et al., 2008) documented them in three caves in the Lehman Creek watershed (Fig. 1): Lehman, Lehman Annex, and Root Caves. Taylor et al. (2008) stated that they were likely facultative trogloxenes but not easily observed. This study had 163 total events showing mice, but most of those were at night, which may account for the difficulty of finding them during standard biological inventories conducted during the day.

I was unable to detect a significant effect of entrance size, length of cave, habitat, and presence or absence of a gate on cave entrance utilization by overall wildlife. However, certain taxa appeared to have preferences. Due to the low sample size of eight caves, it may be easy to oversimplify. For example, $95 \%$ of bats were photographed at gated, long caves in riparian areas, but looking more closely at the data, $71 \%$ of all bats seen were at just one cave (System's Key Cave). Although it is not surprising that bats were found in the longer caves, it is unknown why chipmunks would prefer entrances of long caves. While several abundant taxa showed an inclination to certain cave entrance characteristics, mice had no preferences for gated/ungated, habitat, or length of cave.

The percentage of unknown events per cave varied from just over one tenth of the events (13.0 and 13.5\% for Three Hole Cave and Ice Cave, respectively) to around half of the events (46.4 and 51.9\% for Fox Skull Cave and Model Cave, respectively). These differences may reflect different sensitivities of the kinds of cameras, the presence of wildlife that vary in detectability, changes in lighting, triggers due to movement of vegetation due to wind, or differences in appropriateness of positioning of the cameras. In any case, the use of different types of cameras at different cave entrances was a constraint on interpreting the results (Kelly and Holub, 2008). However, Hughson et al. (2010) found that even using the same model of camera, detection probability can vary greatly. Although some cameras can be programmed to take multiple photos per trigger, only an additional $5 \%$ of wildlife species were captured in this study by the second photo and $2 \%$ by the third photo. The value of this additional identification should be weighed against the amount of time needed to sort through a much larger data set. The second and third photos did not add additional taxa for any of the caves.

Many camera trap studies focus on one size of target, such as medium- or large-sized mammals (e.g., Swann and Perkins, 2013). This study analyzed all sizes, and the cameras performed well in this regard. Nevertheless, it should be noted that due to camera limitations, particularly in the passive infrared detection capabilities, some classes of wildlife such as cold-blooded vertebrates are likely underrepresented in this survey. Invertebrates like beetles, flies, and cave crickets, which may be an important nutrient source to the cave (Taylor et al., 2005), are only rarely captured by remote cameras. One way to compensate for this could be to use both time- and motion-triggered settings. With an average of just 1.7 trap events per day per cave, setting time-triggered settings could greatly augment the number of photos to analyze.

Wildlife were observed using cave entrances for a variety of reasons. At Root Cave, photos of a mouse at the cave entrance were closely followed by that of a gray fox (Fig. 8), suggesting the fox may have been hunting. At 


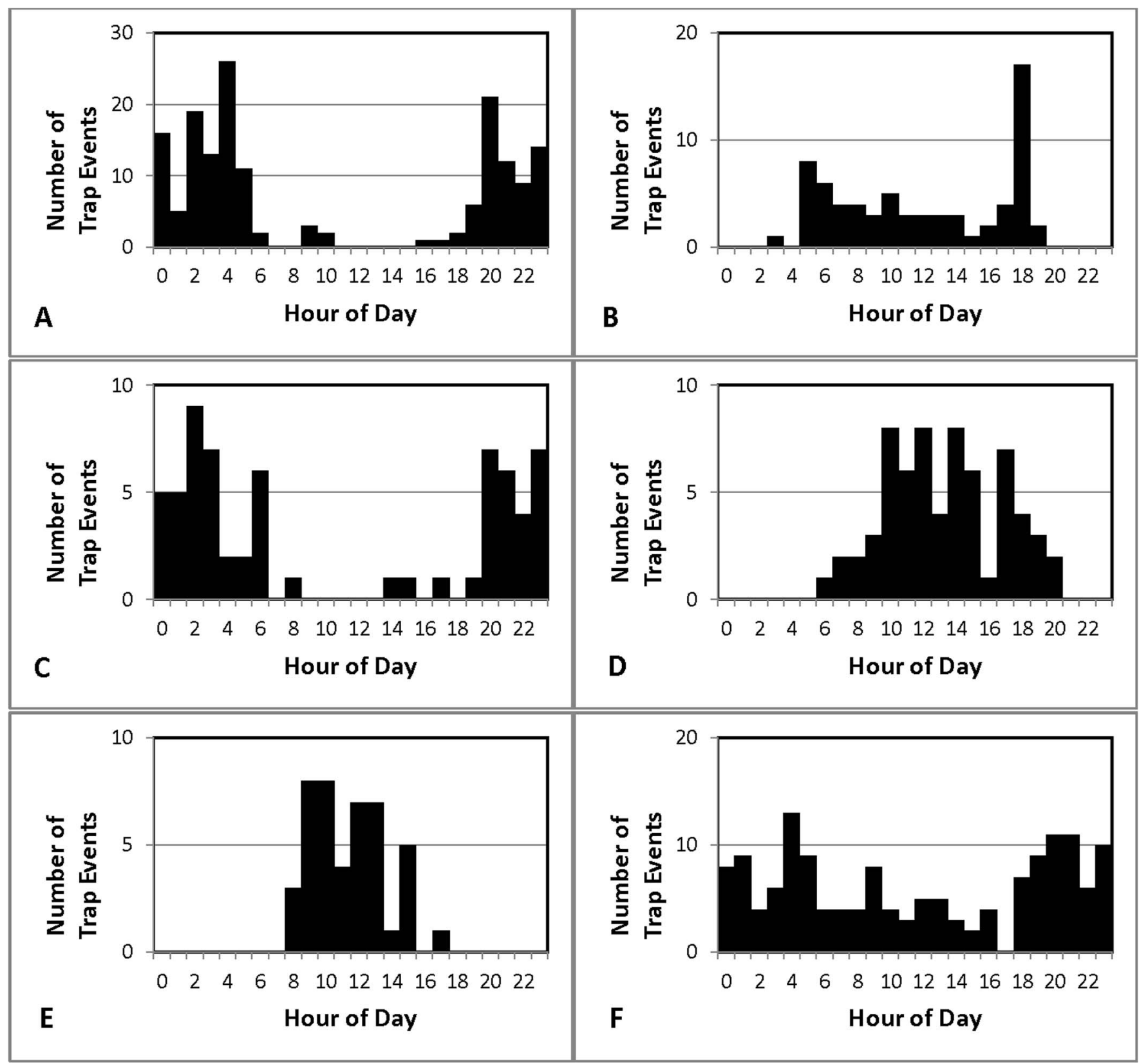

Figure 5. Total number of wildlife camera trap events by taxa pooled by hour of day for all eight caves sampled in Great Basin National Park, White Pine County, Nevada. Shown in order of abundance, except for unknown: A-mouse (Peromyscus cf. maniculatus), B-cliff chipmunk (Tamias dorsalis), C-desert woodrat (Neotoma lepidus), D-human (Homo sapiens), E-rock squirrel (Otospermophilus variegatus), F-unknown trigger.

System's Key Cave, a mouse was photographed eating a fly. The Three Hole Cave entrances may be a resting location for skunks, given their coming and going at intervals. Desert woodrats and small mice are clearly using cave entrances as a home and may enter and leave the caves multiple times per day. For this reason, using camera traps to estimate abundance is not advisable, as the same individuals are likely photographed more than once, and in some cases many more times than once. Nevertheless, the camera traps can 206 - Journal of Cave and Karst Studies, December 2015 be valuable for documenting wildlife interactions with each other and their environment that help augment the understanding of cave ecology (Baker et al., 2014).

With the exception of Upper Pictograph Cave, this study did not target any caves with known bat maternity colonies. This study found bat use of four caves with previous documented bat use, did not find bats in three caves with previous documented bat use, and did not find bat use in one cave with no previous bat use documented (unpublished 


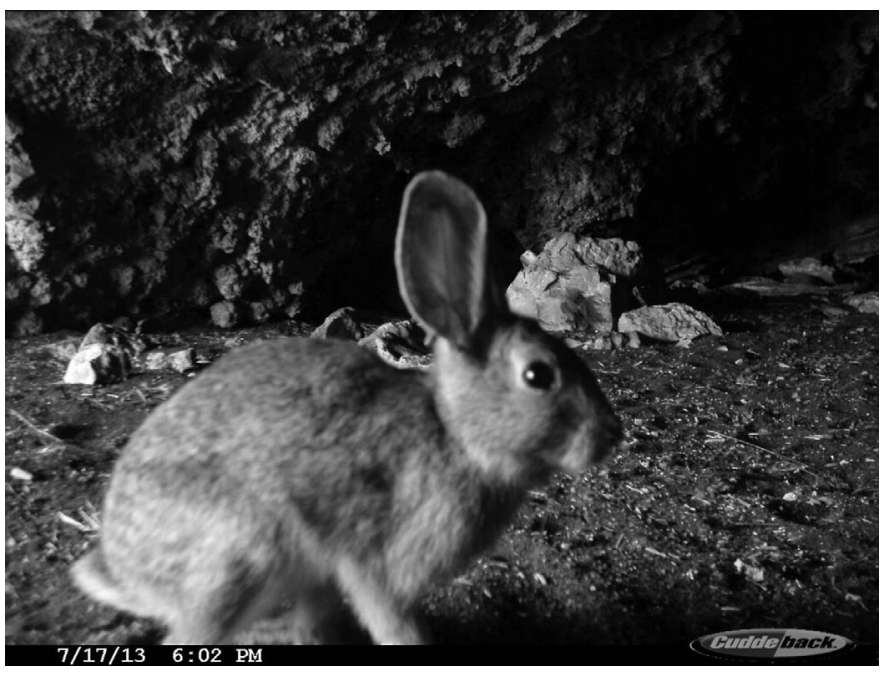

Figure 6. A mountain cottontail (Sylvilagus nuttallii) photographed with a wildlife camera at the entrance of Fox Skull Cave, Great Basin National Park, White Pine County, Nevada.

bat data for Great Basin National Park). This study augmented previous bat data by adding to the months of observed bat use for two caves. The times of bat outflight and inflight varied. The bats were captured primarily in gated caves. It is possible that bats may be flying fast enough that they escaped capture by the camera traps except in caves that have gates, where the bats may be flying more slowly to navigate the bars of the gate. Hirakawa (2005) used a pencil eraser connected to a line to attract bats searching for prey and to slow them sufficiently for camera traps, However, a non-photographic approach such as an infrared beam counter or acoustic loggers may be more appropriate (Wilson, 2000; MacSwiney et al., 2008; Blumstein et al., 2011).

The photographs indicate that temporal-niche partitioning is occurring at some cave entrances. Mice and woodrats were most abundant from 1900 to 0700 , with only $6 \%$ of either species seen from 0700 to 1900 . Meanwhile, chipmunks and humans were predominant from 0600 to 2000, with only $13 \%$ and $3 \%$ respectively from 2000 to 0600 . Squirrels showed an even narrower range of use, with all captured from 0800 to 1500 . Trap events classified as unknown occurred fairly consistently across the 24 hours, further adding credence that camera positioning may be a large reason for those unknowns. Other remote camera studies have documented temporal-niche partitioning, but have focused on medium-sized mammals (Fedriani et al., 2000, Almeida Jácomo et al., 2004). Lower Pictograph Cave, the only cave with high human visitation in this study, is readily visible to human visitors to the park, as it has a large entrance and is located right next to a publicly accessible road. All other caves in this study are less accessible and less visible to casual park visitors. Human visitation to

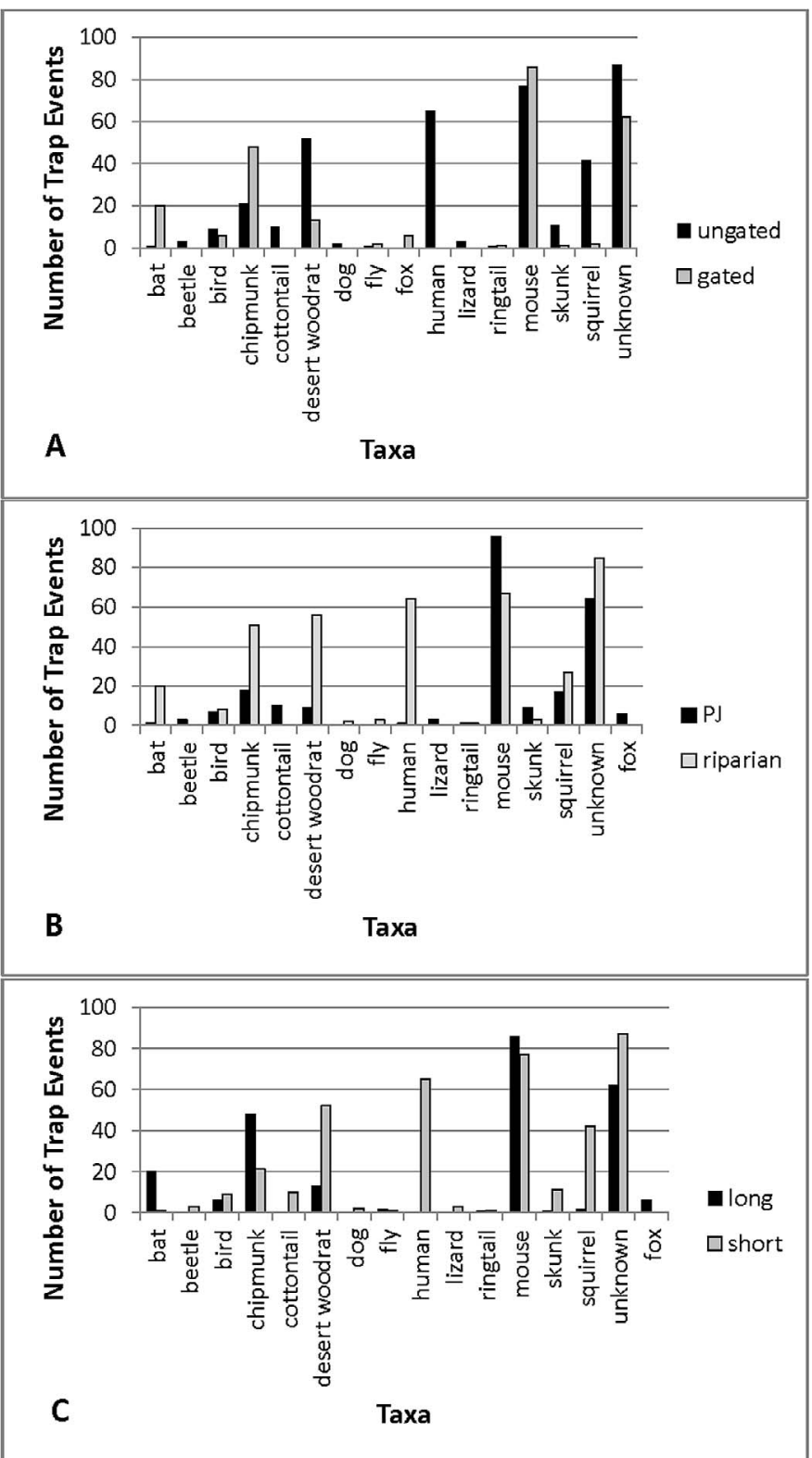

Figure 7. Number of wildlife camera trap events pooled for all caves by species in Great Basin National Park, White Pine County, Nevada. A-gated vs. ungated caves, B-pinyon/ juniper vs. riparian habitat, $C-$ long $(>100 \mathrm{~m})$ vs. short $(<100 \mathrm{~m})$ caves.

Lower Pictograph Cave clearly showed humans visiting the cave entrance to observe and photograph the pictographs (Fig. 9). This human visitation to Lower Pictograph Cave did not entirely preclude wildlife use, although the cave entrance had fewer species than nearby Three Hole or System's Key caves.

Some taxa expected to appear in this study, such as mountain lions and bobcats (Rickart and Robson, 2008), did not show up at any of the camera traps. Other cameratrap studies have shown that at least one thousand trap

Journal of Cave and Karst Studies, December 2015 • 207 


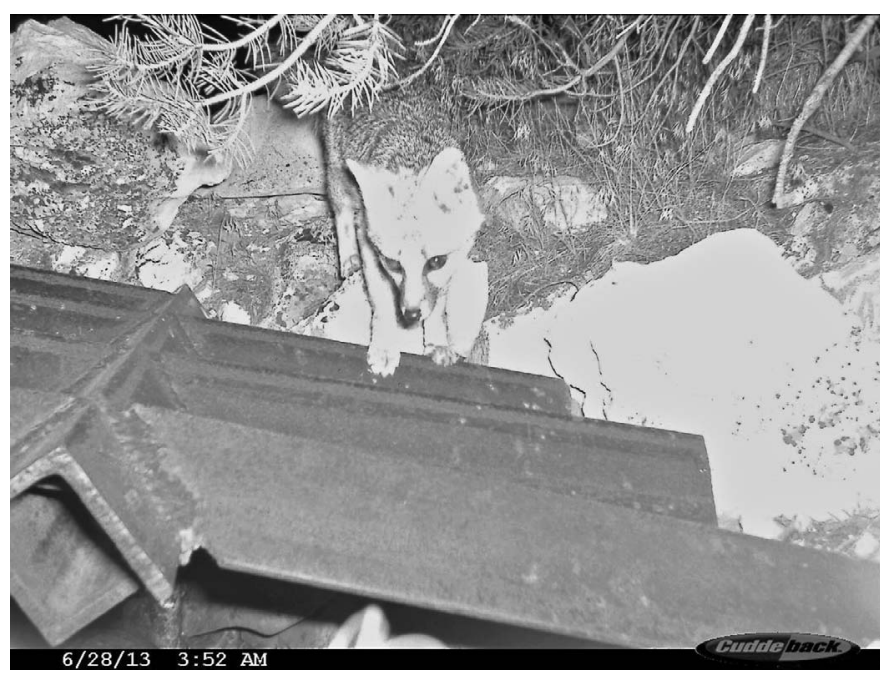

Figure 8. This wildlife camera photo of a gray fox (Urocyon cinereoargenteus) was immediately preceded by a photograph of a mouse at the same location, suggesting the fox was hunting at the entrance to Root Cave, Great Basin National Park, White Pine County, Nevada.

days are needed in an area to infer that a species is absent (Carbone et al., 2001). In addition, for some species, remote photography may not be the best tool; for example, Harrison (2006) found a dog trained to find bobcat scats was superior in New Mexico. Park staff have noted mountain lion tracks entering a cave in the winter (M. Horner, pers. comm.). In addition, in the winter some species hibernate (e.g., western fence lizard) or migrate (e.g., hummingbirds), so it is likely that different fauna are using the cave entrances at different seasons, and conducting seasonal inventories would provide a fuller picture of wildlife use of cave entrances.

Determining the ideal length of time to conduct a similar cave-entrance study is important for future study designs and efficient research-resource allocation. An asymptote of species accumulation was only found with Fox Skull Cave, with seven species reached at 22 days and no additional species added through the 62 day monitoring period (Fig. 3). The other seven caves did not reach an asymptote, including the three caves with over 50 days of sampling. System's Key Cave appeared to have an asymptote with five species at day 30 , but then at day 58 a spotted skunk appeared. This long period of accumulation is different from that seen by Silveira et al. (2003), who found that species richness increased for about 34 days when they used camera traps in grasslands of central Brazil. However, Tobler et al. (2008) estimated the need of 400 to 500 camera days for a camera-trap array to capture the most common medium- to large-sized mammals in rainforests, and 2,000 days to get nearly all. Rovero et al. (2013) recommend 1,000 to 2,000 trap-days to get 60 to $70 \%$ of the species. Clearly longer camera-trap studies

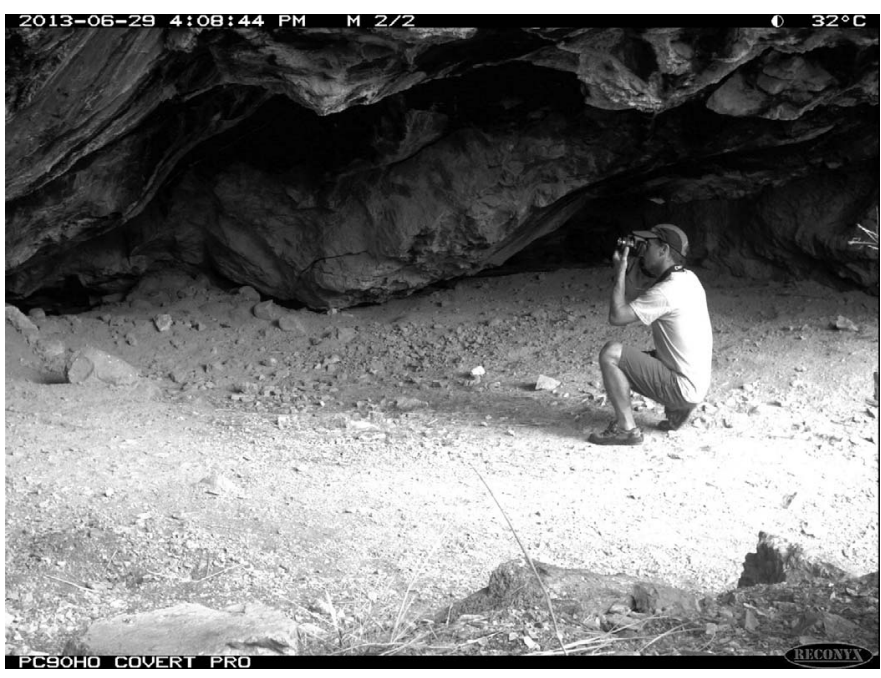

Figure 9. A human visitor photographing the pictographs at the cave entrance to Lower Pictograph Cave, Great Basin National Park, White Pine County, Nevada.

at cave entrances are needed to determine the ideal time needed to capture species richness.

Some caves studied in the Baker Creek drainage are located within 65 to $800 \mathrm{~m}$ of each other, yet the camera traps did not record the same species. For example, skunks were found only at System's Key Cave, Three Hole Cave, and Ice Cave, but not at Lower Pictograph Cave or Wheeler's Deep Cave. This suggests that some species are more particular about the cave habitat they use. Future studies could incorporate more physical measurements such as air temperature and relative humidity, as well as topography, access, or amount of human use in conjunction with the camera traps. The inclusion of these covariates could assist in conducting occupancy estimation, if desired (O'Connell and Bailey, 2011).

\section{Conclusions}

Very little information has been documented about what fauna use cave entrances. This non-invasive technique using camera traps can help managers learn about the dominant species using the entrance and twilight areas of the caves they manage, as well as supplement cave bioinventories. Although the cost of camera trapping may initially be high if new equipment must be purchased, it is preferred over track surveys and direct counts for rapid faunal assessments of mammals (Silveira et al., 2003). Remote cameras can often be borrowed from wildlife or law enforcement programs. Using remote cameras at cave entrances is easily repeatable, which would allow for monitoring to determine changes in a measure such as species richness over time.

The use of camera traps to do this inventory of eight cave entrances in summer at Great Basin National Park 
worked well, with some caveats that serve as recommendations for others who would like to use this technique for inventorying wildlife at cave entrances in their area:

1. Use the same make and model of camera if possible at all cave entrances;

2. Use cameras with both infrared and motion detection to improve trapping rates;

3. Three photos per trigger result in $7 \%$ more identifications, but three times more photos to process, adding little to the understanding of site usage by wildlife;

4. Install cameras for a minimum of 60 days at each cave entrance to capture most of the wildlife species using it; longer is better;

5. Measure covariates, as listed above, if trying to account for why species may or may not be present at a particular cave entrance; and

6. Sample during different seasons and for subsequent years to obtain a stronger dataset.

Camera traps are a useful tool for conducting wildlife inventories of cave entrances. They can be broadly applied to caves throughout the world.

\section{AcKNowledgements}

Thanks to Margaret Horner, who taught me to program remote cameras, reviewed selected wildlife species in photos, and provided review comments. Jonathan Reynolds also assisted with programming remote cameras, and Kevin Wheeler identified the birds in the photos. Bryan Hamilton, Tod Williams, Keith Dunlap and two anonymous reviewers provided comments that improved this manuscript.

\section{REFERENCES}

Almeida Jácomo, A.T., Silveira, L., and Diniz-Filho, J.A.F., 2004, Niche separation between the maned wolf (Chrysocyon brachyurus), the crab-eating fox (Dusicyon thous) and the hoary fox (Dusicyon vetulus) in central Brazil: Journal of Zoology, v. 262, p. 99-106. doi:10.1017/ S0952836903004473.

Baker, G.M., Taylor, S.J., Thomas, S., Lavoie, K., Olson, R., Barton, H., Denn, M., Thomas, S.C., Ohms, R., Helf, K.L., Despain, J., Kennedy, J., and Larson, D., 2014, Cave Ecology Inventory and Monitoring Framework: Natural Resource Report NPS/NRPC/NRR—2015/948: National Park Service, Fort Collins, Colorado, $140 \mathrm{p}$.

Barr, T.C., Jr., and Holsinger, J.R., 1985, Speciation in cave faunas: Annual Review of Ecology and Systematics, v. 16, p. 313-337. doi: 10.1146/annurev.es.16.110185.001525.

Blumstein, D.T., Mennill, D.J., Clemins, P., Girod, L., Yao, K., Patricelli, G., Deppe, J.L., Krakauer, A.H., Clark, C., Cortopassi, K.A., Hanser, S.F., McCowan, B., Ali, A.M., and Kirshcel, A.N.G., 2011, Acoustic monitoring in terrestrial environments using microphone arrays: Applications, technological considerations and prospectus: Journal of Applied Ecology, v. 48, p. 758-767. doi:10.1111/j.1365-2664.2011. 01993.x.

Carbone, C., Christie, S., Conforti, K., Coulson, T., Franklin, N., Ginsberg, J.R., Griffiths, M., Holden, J., Kawanishi, K., Kinnaird, M., Laidlaw, R., Lynam, A., Macdonald, D.W., Martyr, D., McDougal, C., Nath, L., O'Brien, T., Seidensticker, J., Smith, D.J.L., Sunquist,
M., Tilson, R., and Wan Shahruddin, W.N., 2001, The use of photographic rates to estimate densities of tigers and other cryptic mammals: Animal Conservation, v. 4, p. 75-79. doi:10.1017/S136794300 1001081.

Cigna, A.A., 2004, Climate of caves, in Gunn, J., ed., 2004, Encyclopedia of Caves and Karst Science. New York: Taylor and Francis, p. $228-230$.

Culver, D.C., Hobbs III, H.H., Christman, M.C., and Master, L.L., 1999, Distribution map of caves and cave animals in the United States: Journal of Cave and Karst Studies, v. 61, p. 139-140.

Desert Research Institute, 1968, Final Reports on the Lehman Caves Studies to the Department of the Interior, National Park Service, Lehman Caves National Monument: Reno, Nevada, The Laboratory of Desert Biology, Desert Research Institute.

Elliott, P.E., Beck, D.A., and Prudic, D.E., 2006, Characterization of surface-water resources in the Great Basin National Park area and their susceptibility to ground-water withdrawals in adjacent valleys, White Pine County, Nevada: U.S. Geological Survey Scientific Investigations Report 2006-5099, 156 p.

Fedriani, J.M., Fuller, T.K., Sauvajot, R.M., and York, E.C., 2000, Competition and intraguild predation among three sympatric carnivores: Oecologia, v. 125, p. 258-270. doi:10.1007/s004420000448.

Graham, J.P., 2014, Great Basin National Park: Geologic Resources Inventory Report: Natural Resource Report NPS/NRSS/GRD/ NRR - 2014/762, National Park Service, Fort Collins, Colorado, 86 p.

Harrison, R.L., 2006, A comparison of survey methods for detecting bobcats: Wildlife Society Bulletin, v. 34, p. 548-552. doi:10.2193/00917648(2006)34[548:ACOSMF]2.0.CO;2.

Hirakawa, H., 2005, Luring bats to the camera-A new technique for bat surveys: Mammal Study, v. 30, p. 69-71. doi:10.3106/1348-6160 (2005)30[69:LBTTCA]2.0.CO;2.

Hose, R.K., and Blake, M.C., Jr., 1976, Geology and mineral resources of White Pine County, Nevada, Part I. Geology: Reno, Nevada Bureau of Mines and Geology, Mackay School of Mines, University of Nevada, Bulletin 85, p. 1-35.

Hughson, D.L., Darby, N.W., and Dungan, J.D., 2010, Comparison of motion-activated cameras for wildlife investigations: California Fish and Game, v. 96, no. 2, p. 101-109.

Kelly, M.J., and Holub, E.L., 2008, Camera trapping of carnivores: trap success among camera types and across species, and habitat selection by species, on Salt Pond Mountain, Giles County, Virginia: Northeastern Naturalist, v. 15, p. 249-262. doi:10.1656/1092-6194(2008)15[249: CTOCTS]2.0.CO;2.

Krejca, J.K. and Taylor, S.J., 2003, A Biological Inventory of Eight Caves in Great Basin National Park: Illinois Natural History Survey, Center for Biodiversity Technical Report 2003(27), 72 p.

Kucera, T.E., and Barrett, R.H., 2011, A history of camera trapping, in O'Connell, A.F., Nichols, J.D., and Karanth, K.U., eds., 2011, Camera Traps in Animal Ecology: Methods and Analyses, Tokyo, Japan, Springer, p. 9-26. doi:10.1007/978-4-431-99495-4_2.

MacSwiney, G., M.C., Clarke, F.M., and Racey, P.A., 2008, What you see is not what you get: The role of ultrasonic detectors in increasing inventory completeness in Neotropical bat assemblages: Journal of Applied Ecology, v. 45, p. 1364-1371. doi:10.1111/j.1365-2664.2008. 01531.x.

Miller, E.L., and the Stanford Geological Survey, 2007 (mapping 19931997), Geologic map of Great Basin National Park and environs, Southern Snake Range, Nevada: Palo Alto, Stanford Geological Survey, (scale 1:24,000). http://www.nature.nps.gov/geology/inventory/ publications/map_graphics/grba_geologic_map_graphic_print.pdf.

O'Connell, A.F., and Bailey, L.L., 2011, Inference for occupancy and occupancy dynamics, in O'Connell, A.F., Nichols, J.D., and Karanth, K.U., eds., 2011, Camera Traps in Animal Ecology: Methods and Analyses, Tokyo, Japan, Springer, p. 191-204. doi:10.1007/978-4-431-99495-4_11.

Reinemann, S.A., Patrick, N.A., Baker, G.M., Porinchu, D.F., Mark, B.G., and Box, J.E., 2011, Climate change in Great Basin National Park: Lake sediment and sensor-based studies: Park Science, v. 28, no. 2, p. 31-35.

Rickart, E.A. and Robson, S.L., 2008, A Guide to the Mammals of Great Basin National Park: Salt Lake City, Utah Museum of Natural History Report: University of Utah, $95 \mathrm{p}$.

Rovero, F., Zimmermann, F., Berzi, D., and Meek, P., 2013, Which camera trap type and how many do I need? A review of camera features and study designs for a range of wildlife research applications: Hystrix, the 
Italian Journal of Mammalogy, v. 24, p. 148-156. doi:10.4404/hystrix24.2-8789.

Silveira, L., Jácomo, A.T.A., and Diniz-Filho, J.A.F., 2003, Camera trap, line transect census and track surveys: A comparative evaluation: Biological Conservation, v. 114, p. 351-355. doi:10.1016/S0006-3207(03) 00063-6.

Stark, N, 1969, Microecosystems in Lehman Cave, Nevada: National Speleological Society Bulletin, v. 31, no. 3, p. 73-81.

Strong, T.S., 2006, Vertebrate species use of cave resources in the Carlsbad Caverns region of the Chihuahuan Desert, in Harmon, D., ed., 2006, People, Places, and Parks: Proceedings of the 2005 George Wright Society Conference on Parks, Protected Areas, and Cultural Sites: Hancock, Michigan, The George Wright Society, Hancock, MI, p. $270-276$.

Strong, T.R., 2010, Vertebrate species in desert caves and mines - A comparison between the Chihuahuan and Sonoran deserts, in Halvorson, W., Schwalbe, C., and Van Riper III, C., ed., Southwestern Desert Resources: Phoenix, University of Arizona Press, p. 93-106.

Swann, D.E., and Perkins, N., 2013, Inventory of terrestrial mammals in the Rincon Mountains using camera traps, in Gottfried, G.J., Ffolliott, P.F., Gebow, B.S., Eskew, L.G., Collins, L.C., eds., Merging Science and Management in a Rapidly Changing World: Biodiversity and
Management of the Madrean Archipelago III and 7th Conference on Research and Resource Management in the Southwestern Deserts; 2012 May 1-5: Fort Collins, Colorado, U.S. Department of Agriculture, Forest Service Proceedings RMRS-P-67, p. 269-276.

Taylor, S.J., Krejca, J.K., and Slay, M.E., 2008, Cave biota of Great Basin National Park, White Pine County, Nevada: Illinois Natural History Survey Technical Report INHS 2008 (25), 398 p.

Taylor, S.J., Krejca, J.K., and Denight, M.L., 2005, Foraging range and habitat use of Ceuthophilus secretus (Orthoptera: Rhaphidophoridae), a key trogloxene in central Texas cave communities: The American Midland Naturalist, v. 154, p. 97-114. doi:10.1674/0003-0031(2005) 154[0097:FRAHUO]2.0.CO;2.

Tobler, M.W., Carrillo-Percastegui, S.E., Leite Pitman, R., Mares, R., and Powell, G., 2008, An evaluation of camera traps for inventorying largeand medium-sized terrestrial rainforest mammals: Animal Conservation, v. 11, no. 3, p. 169-178. doi:10.1111/j.1469-1795.2008.00169.x.

Wilson, P.D., 2000, Using infrared technology to monitor bat activity: A resource for experimenters: Winmalee, New South Wales, Bionomic Ecological Consulting,

Winkler, W.G., and Adams, D.B., 1972, Utilization of southwestern bat caves by terrestrial carnivores: The American Midland Naturalist, v. 87, p. 191-200. doi:10.2307/2423892. 